\title{
Efek Campuran Lemon Dan Minyak Zaitun (Lezat) Terhadap Kadar Kolesterol Pasien Hipertensi
}

\section{Effects Mixtures of Lemon and Virgin Olive Oil on The Cholesterol Levels of Hypertensive Patients}

\author{
Dwi Kartika Rukmi ${ }^{1 *}$, Rizqi Wahyu Hidayati ${ }^{2}$, Tetra Saktika Adinugraha ${ }^{3}$ \\ ${ }^{1,2,3}$ Universitas Jenderal Achmad Yani Yogyakarta, Jalan Ringroad Barat, Gamping Kidul, Ambarketawang, Kec. Gamping, \\ Kab. Sleman, Yogyakarta 55294, Indonesia \\ kartikarukmi@gmail.com*, ririzpl@gmail.com \\ * corresponding author \\ Tanggal Submisi: 13 November 2021, Tanggal Penerimaan: 8 Februari 2021
}

\begin{abstract}
Abstrak
Penelitian ini mengevaluasi pengaruh pendek campuran lemon dan minyak zaitun terhadap kadar kolesterol pasien hipertensi. Penelitian quasi eksperimental dengan pretest-posttest without control group design dilakukan pada 18 pasien hipertensi dengan purposive sampling. Sampel menerima campuran $30 \mathrm{ml}$ lemon dan $30 \mathrm{ml}$ minyak zaitun, sekali sehari 30 menit sebelum sarapan selama 14 hari. Kadar kolesterol diukur sehari sebelum (hari 0) dan hari ke-14 pemberian. Kadar kolesterol rata-rata pretest adalah 265,83 \pm 53,52 $\mathrm{mg} / \mathrm{dl}$, dan posttest adalah 228,67 $\pm 55,14 \mathrm{mg} / \mathrm{dl}$. Hasil uji-T sampel berpasangan terdapat perbedaan yang bermakna pada kadar kolesterol pasien $(p=0,023 ; p<0,05)$.
\end{abstract}

Kata kunci : hipertensi; lemon; minyak zaitun; kolesterol; keperawatan

\begin{abstract}
The study evaluated the effect of mixtures of lemon and virgin olive oil on the cholesterol level in hypertension patients. A quasi-experimental study, with a pretest-posttest without control group design, did on 18 purposively sampling hypertension patients. Samples received mixtures of $30 \mathrm{ml}$ lemon squeeze and $30 \mathrm{ml}$ virgin olive oil once a day 30 minutes before breakfast for 14 days. The cholesterol level was measured the day before (day 0 ) and the $14^{\text {th }}$ days of administration. The pretest's mean cholesterol level was $265.83 \pm 53.52 \mathrm{mg} / \mathrm{dl}$, and the posttest was $228.67 \pm 55.14 \mathrm{mg} / \mathrm{dl}$. Paired sample T-test showed significant differences before and after administration of mixture $(\mathrm{p}=0.023 ; \mathrm{p}<0.05)$.
\end{abstract}

Keywords: Hypertension, Lemon, Virgin Olive Oil, Cholesterol, Nursing

\section{INTRODUCTION}

Cardiovascular disease is the leading cause of death in various developing and developed countries (Oboh, Bello, Ademosun, Akinyemi, \& Adewuni, 2015). The study shows that the disease caused by multi-factors, such as genetic and environmental factors, plays a role in cardiovascular disease (Choudhury, Mainuddin, Wahiduzzaman, \& Islam, 2014; Gupta, Rai, Toppo, Kasar, \& Nema, 2018). Some cardiovascular disease factors that can neither be changed nor controlled include age, gender, race/ethnicity, and family history. At the same time, risk factors that can be altered or controlled include smoking, alcohol, obesity, dyslipidemia, diabetes mellitus, and hypertension (Budiman, Sihombing, \& Pradina, 
2015). Hypertension can increase the workload of the heart. Continuously high blood pressure causes the arteries' damage because of the slowly hardened arteries experience (atherosclerosis) and the coronary occlusion (Budiman et al., 2015). Endothelial dysfunction is a phenomenon regarding the development of atherosclerosis and cardiovascular disease in hypertensive patients (Moreno-Luna et al., 2012). The endothelial dysfunction is characterized by a marked decrease in bioavailability of nitric oxide (NO) and increased levels of oxidized low-density lipoprotein (LDL). One of the predominant mechanisms in the NO inactivation is a change L-arginine-NO pathway by oxidative stress. It is resulting in increased plasma level asymmetric dimethylarginine (ADMA). Rising of ADMA will lead to the deterioration in the oxidation stress that occurs. The activity reduction of dimethylarginine dimethylaminohydrolase (DDAH) by reactive oxygen species increases intracellular ADMA accumulation that contributes to ADMA exports. Both pro-oxidant status and increased ADMA are regarded as conditions linked to atherosclerosis and hypertension(Moreno-Luna et al., 2012).

Dyslipidemia defined as a disorder of lipid metabolism characterized by an increase or decrease in the lipid fraction of the plasma. The significant lipid abnormalities fraction are the increase in the total number of cholesterol (C-total), LDL cholesterol (C-LDL), triglycerides (TG), and the decrease in the HDL cholesterol (C-HDL)(Arsana et al., 2015).Dyslipidemia is a risk factor for atherosclerosis. The disruption of the lipid profile in the blood is an accumulation of fat in the lining of blood vessels, which ultimately reduces the blood vessel lumen diameter as a result of ischemia with subsequent manifestations of infarction(Budiman et al., 2015). Therefore, hypertension must be properly managed so that it does not have a worse impact on the sufferer. Hypertension management can be generated using drugs or lifestyle modification (Kemenkes.RI, 2014). Although pharmacological treatment has a significant result in decreasing blood pressure and dyslipidemia, lifestyle modification, and diet improvement are crucial in cardiovascular disease management (Aslani, Entezari, Askari, Maghsoudi, \& Maracy, 2016). Vegetables and fruits contain different phytochemicals in line with anti-inflammatory and vascular reactivity (Aslani et al., 2016; Moreno-Luna et al., 2012). Some foods that are believed to be useful for reducing inflammation and improving endothelial function include olive oil and lemon.

As a family of citrus fruits, lemon (Citrus limon) has long been known as healthy food. It is because lemon is a fruit rich in eriocitrin and hesperidin flavones. Lemon can be consumed directly by squeezing or making juice (Oboh et al., 2015). Olive oil (Olea europea) is the primary fat source and believed to be the healthiest source of fat in the Mediterranean $\operatorname{diet}($ Covas, De La Torre, \& Fitó, 2015). In Olive Oil, minor components found are phenolic compounds, which are potent antioxidants that provide significant benefits in health(MorenoLuna et al., 2012). Virgin Olive Oil (VOO) type of olive oil is rich in phenolic compounds, and the European Food Safety Authority has also released benefits from daily consumption of VOO, which is rich in phenolic compounds in November 2011(Covas et al., 2015). Some researches on the effects of olive and lemon oils on reducing inflammatory biomarkers and lipid profiles include total cholesterol in patients with cardiovascular disease have been undertaken separately. In comparison, topics on mixtures of lemon juice (Citrus lemon) and virgin olive oil (Olea europea) in this research are under-researched. For addition, the results of a preliminary study found that many hypertension patients in Gilangharjo village had a history of hypercholesterolemia, and they admitted that they would be happy if there were a natural therapy to lower cholesterol. Therefore, this study aimed to see virgin olive oil and lemon juice combined in lowering cholesterol in hypertensive patients. 


\section{METHOD}

\section{Study design}

This research has passed ethical clearance from Jenderal Achmad Yani Yogyakarta University's ethics committee. This pre-experiment research was conducted on 18 hypertension patients using purposive sampling in Gilangharjo Village, Pandak, Bantul, Yogyakarta in August 2018. This research used one group pretest and posttest without control design.

\section{Sample}

Samples selected with inclusion criteria as hypertension patients with minimum age 30 years old who routinely seek treatment, have a cellular telephone with video features, have social or communication media to send videos, and do not take drugs to cholesterol/fat-lowering during the study. Samples who have a sensitive gastrointestinal tract and refused to drink the mixture before breakfast were excluded.

\section{Lemon and virgin olive oil mixture preparation}

The guidelines for making the mixture was adopted and modified from the research conducted by Hasan et al. and Khan et al.(Hasan, Singh, Siddiqui, Kulshreshtha, \& Aggarwal, 2013; Khan, Khan, Afroz, \& Siddiq, 2010). The way to make the mixture is using a lemon (Citrus limon) and virgin olive oil (Olea europea). After the two ingredients obtained, the lemon then squeezed using a squeezing device. The lemon juice results are taken as much as $30 \mathrm{ml}$, and mixed with $30 \mathrm{ml}$ of virgin olive oil. After being mixed, lemon and virgin olive oil are then stirred and taken immediately 30-60 minutes after breakfast.

\section{Data Collection}

Data obtained through the scheme:

1. Day 0: In the afternoon, eligible samples got explaining the purpose and course of the study.

2. Samples who are willing to participate in the study signed informed consent and taught how to make the mixture correctly.

3. Samples were collected and checked for cholesterol levels before treatment (pretest).

4. Before returning home, the sample provided with the mixture making guidelines, 500 $\mathrm{ml}$ virgin olive oil, orange squeezer, measuring cup, and five medium-sized lemons.

5. Days 1 - 14: Respondents drank the mixture made according to the guidelines every morning 30 -60 minutes before breakfast for 14 consecutive days. When drinking the mixture, the respondent is obliged to record the activity then send the video recordings to the research or research assistant every day.

6. Lemon preparations were given for five days of stocks. Every five days, researcher assistants come to the respondent's house to check the intervention needs (checklist and other ingredients) and possible obstacles (drop out, failure).

7. Day 14: In the afternoon, samples who have carried out a complete intervention for drinking the mixture for 14 days without being missed are visited one by one and rechecked the cholesterol (posttest).

\section{Data Analysis}

Data were analysed using the Paired Sample T-Test because it met the data normality test requirements. 


\section{Ethical Clearance}

This research has passed the ethical clearance from Jenderal Achmad Yani University with number Skep / 374 / KEPK / VI / 2018.

\section{RESULTS AND DISCUSSION \\ Results}

The demographic data of the study presented in table 1. Finding the demographic data shows that the majority of respondents were women (83\%) with BMI categories above average (44.4\% Overweight and $11.2 \%$ Obesity), all of them have Type II Diabetes mellitus $(100 \%)$, and the average age of $57.1 \pm 9.75$ years.

Table 1. Demographic Characteristics of Hypertension Patients in Gilangharjo $(\mathrm{n}=18)$

\begin{tabular}{llcc}
\multicolumn{1}{c}{ Characteristic } & $\sum$ & $\%$ \\
\hline \multirow{2}{*}{ Gender } & Man & 3 & 17 \\
& Woman & 15 & 83 \\
\hline \multirow{2}{*}{ BMI } & Normal & 8 & 44,4 \\
& Overweight & 8 & 44,4 \\
& Obese & 2 & 11,2 \\
\hline DM & Yes & 18 & 100 \\
& No & 0 & 0 \\
\hline & Mean & Min-Max & DS \\
\hline & 57.1 & $44-81$ & 9.75 \\
\hline
\end{tabular}

Table 2. Pretest and Posttest of Cholesterol Levels in Lemon and Virgin Olive Oil Mixture Administration (n=18)

\begin{tabular}{lllrc}
\hline Cholesterol & Mean & N & Min-Max & SD \\
\hline Pretest & 265,83 & 18 & $200-400$ & 53,52 \\
\hline Posttest & 228,67 & 18 & $160-340$ & 55,14 \\
\hline
\end{tabular}

Table 2 shows that the average cholesterol level ahead of the mixture administration (pretest) was $265.83 \pm 53.52 \mathrm{mg} / \mathrm{dl}$ and the average cholesterol level after the mixture (posttest) administration was $228.67 \pm 55.14 \mathrm{mg} / \mathrm{dl}$, meaning that there was a change in the form of reducing cholesterol levels by $37.17 \mathrm{mg} / \mathrm{dl}$.

Table 3. A paired t-test of Lemon and Virgin Olive Oil Mixture Administration (n=18)

\begin{tabular}{cccccc} 
Variable & Mean & SD & t & df & pv \\
\hline Cholesterol level & 37.167 & 62.985 & 2.504 & 17 & .023 \\
\hline
\end{tabular}

Table 3 shows the results of the Paired Sample T cholesterol test along with the final result pv $=0.023(<0.05)$, which means that there are significant differences in cholesterol levels of hypertensive patients in Gilangharjo Village, Pandak, Bantul, Yogyakarta after the administration of a mixture of lemon and virgin olive oil.

\section{Discussion}

This research aims to determine the effects of a mixture of lemon juice and virgin olive oil on the reduction of cholesterol levels in hypertensive patients in Gilangharjo village, Pandak, Bantul, Yogyakarta. The results of the paired sample t-test statistical test proved that there were significant differences $(\mathrm{p}=0.023)$ of cholesterol levels in hypertensive patients in Gilangharjo Village, Pandak, Bantul, Yogyakarta before and after the treatment of a mixture 
of lemon and virgin olive oil. The results of this study support the results of previous studies conducted by Violante et al. (2009) and Khan et al. (2010), which stated that the provision of virgin olive oil and lemon juice could reduce cholesterol levels in hyper cholesterol patients (Violante, Gerbaudo, Borretta, \& Tassone, 2009; Yasmin, Khan, Syeda, \& Afshan, 2010). However, the results of this study are somewhat different from the results of research conducted by Yuiwarti et al. (2018), which stated that compared to virgin olive oil, virgin coconut oil has more potential to maintain cholesterol in hyperglycemic Rattus rattus norvegicus (Wachidah Yuiwarti, Saraswati, \& Kusdiyantini, 2018).

Several epidemiological studies have reported the use of olive oil on health accordingly. Virgin Olive Oil (VOO) contains many phytochemicals (natural plant chemicals), vitamins, antioxidants, and polyphenols that have been clinically proven to be useful for health through various methods (Hasan et al., 2013). A study by Covas et al.(Covas et al., 2015) outlined that the consumption of virgin olive oil can reduce the risk of heart disease. One way to avoid or minimize the risk of heart disease is to consume unsaturated fatty acids, and virgin olive oil is the best source of unsaturated fatty acids.

Another study by Hasan et al (Hasan et al., 2013) highlighted a case about the importance of giving $30 \mathrm{ml}$ of virgin olive oil every day for six weeks in 30 men who had hyperlipidemia. The results showed a significant decrease in LDL, triglycerides, and total cholesterol, as well as an increase in HDL levels. The oxidized LDL plays an essential role in the case of atherosclerosis. MUFA and some phytochemical contents in pure olive oil produce LDL, which is more resistant to the oxidation process. This results in a reduced effect of oxidation, thrombogenicity, and plaque formation that emerges to protect the body from atherosclerosis (Hasan et al., 2013). Three flavonoids (flavanones, flavones, and flavonols) and more than 60 other flavonoids have been identified from citrus/citrus fruits. Lemon (Citrus limon) is a family of citrus fruits that has long been known as healthy food. This is because lemon is a fruit that is rich in eriocitrin and hesperidin flavones (Oboh et al., 2015).

Citrus limon (lemon) contains a crucial natural component, including citric acid, ascorbic acid, minerals, and flavonoid(Khan et al., 2010). Flavonoids in lemons have several different biological functions, including antioxidants, anti-inflammatory, anti-allergic, antiviral, anti-proliferative, anti-mutagenic, and anti-cyanogenic drugs(Khan et al., 2010). Lemon can be consumed directly by squeezing or making juice (Oboh et al., 2015). Research conducted on rats and rabbits showed that eriocitrin and hesperidin have antioxidant properties, and they can reduce the oxidation stress(Aslani et al., 2016; Boshtam, Naderi, Moshtaghian, Asgary, \& Jafari, 2009). The research conducted by Oboh et al(Oboh et al., 2015) examined that administration of lemon juice in rats given high cholesterol food gave significant results in reducing the total number of cholesterol, triglyceride, and LDL and increasing HDL levels along with the mechanism of inhibiting angiotensin activity -1converting enzyme (ACE).

Considering the administration of lemon juice in rats with a high cholesterol diet intake for four weeks. Khan et al.(Khan et al., 2010) showed that taking $1 \mathrm{ml} / \mathrm{KgWB}$ of juice or lemon juice/day significantly reduced serum cholesterol levels, triglycerides, LDL, and increasing levels of HDL. In short sentences, lemon reduces the risk of heart disease through the content of eriocitrin and hesperidin, which has antioxidant properties. It can reduce the oxidation stress and its ability to reduce the total number of cholesterol, triglycerides, LDL, and increase HDL levels by inhibiting angiotensin-1- converting enzyme activity (ACE). The same combination of two functions between virgin olive oil and lemon can reduce the total number of cholesterol, LDL, triglyceride levels, and increase HDL levels. Thus, the cholesterol levels decreased by $37.17 \mathrm{mg} / \mathrm{dl}$ after respondents underwent lemon and virgin 
olive oil mixtures consumption during 14 days without interruption within 30-60 minutes before breakfast.

\section{CONCLUSION}

Our results showed that the average cholesterol level of the pretest was $265.83 \pm$ $53.52 \mathrm{mg} / \mathrm{dl}$, and the mean cholesterol level of posttest was $228.67 \pm 55.14 \mathrm{mg} / \mathrm{dl}$, meaning that there was a change in cholesterol levels by $37.17 \mathrm{mg} / \mathrm{dl}$. Paired Sample T-Test results obtained $p=0.023(<0.05)$, which means that there are significant differences in cholesterol levels of hypertensive patients in Gilangharjo Village, Pandak, Bantul, Yogyakarta after the treatment of a mixture of lemon and virgin olive oil.

\section{RECCOMENDATION}

Mixture of lemon and virgin olive oil might be useful for community nurses as an additional method to reduce cholesterol in hypertension patients.

\section{Acknowledgments}

The authors would like thank to L2DIKTI Wilayah V, Jalan Tentara Pelajar No 13. Yogyakarta. 55231.Email: 1ldikti5@ristekdikti.go.id for the research grant and Puskesmas Pandak I as the research location.

\section{REFERENCES}

Arsana, P. M., Rosandi, R., Manaf, A., Budhiarta, A., Permana, H., Sucipta, K. W., ... Suhartono, T. (2015). Panduan Pengelolaan Dislipidemia di Indonesia. PB Perkeni, 4.

Aslani, N., Entezari, M. H., Askari, G., Maghsoudi, Z., \& Maracy, M. R. (2016). Effect of garlic and lemon juice mixture on lipid profile and some cardiovascular risk factors in people 30-60 years old with moderate hyperlipidaemia: A randomized clinical trial. International Journal of Preventive Medicine, 2016-JULY. https://doi.org/10.4103/2008-7802.187248

Boshtam, M., Naderi, G. A., Moshtaghian, J., Asgary, S., \& Jafari, N. (2009). Effects of citrus limon burm. f. on some atherosclerosis risk factors in rabbits with atherogenic diet. Atherosclerosis, $5(2), 88-93$.

Budiman, Sihombing, R., \& Pradina, P. (2015). Hubungan Dislipidemia, Hipertensi Dan Diabetes Melitus Dengan Kejadian Infark Miokard Akut. STIKES Jenderal Achmad Yani Cimahi, 32-37.

Choudhury, K. N. A., Mainuddin, a. K. M., Wahiduzzaman, M., \& Islam, S. M. O. S. (2014). Serum lipid profile and its association with hypertension in Bangladesh. Vascular Health and Risk Management, 10, 327-332. https://doi.org/10.2147/VHRM.S61019

Covas, M. I., De La Torre, R., \& Fitó, M. (2015). Virgin olive oil: A key food for cardiovascular risk protection. British Journal of Nutrition, 113(S2), S19-S28. https://doi.org/10.1017/S0007114515000136

Gupta, V. K., Rai, N., Toppo, N. A., Kasar, P. K., \& Nema, P. (2018). An epidemiological study of prevalence of hypertension and its risk factors among non migratory tribal population of Mawai block of Mandla district of central India. International Journal Of Community Medicine And Public Health, 5(3), 957. https://doi.org/10.18203/2394-6040.ijcmph20180464

Hasan, S. N., Singh, D., Siddiqui, S. S., Kulshreshtha, M., \& Aggarwal, T. (2013). Original Article Effects of Olive Oil on Lipid Profile in. National Journal of Medical Research, 3(4), 312-314.

Kemenkes.RI. (2014). Pusdatin Hipertensi. Infodatin, (Hipertensi), 1-7. 
https://doi.org/10.1177/109019817400200403

Khan, Y., Khan, R. A., Afroz, S., \& Siddiq, A. (2010). Evaluation of Hypolipidemic effect of Citrus Lemon. Journal of Basic and Applied Sciences, 6(1), 39-43. Retrieved from http://scholar.google.com/scholar?hl=en\&btnG=Search\&q=intitle:Evaluation+of+hypolipidemic +effect+of+citrus+lemon\#0\%5Cnhttp://scholar.google.com/scholar?hl=en\&btnG=Search\&q=int itle:Evaluation+of+hypolipidemic+effect+of+Citrus+lemon $\% 230$

Moreno-Luna, R., Muñoz-Hernandez, R., Miranda, M. L., Costa, A. F., Jimenez-Jimenez, L., VallejoVaz, A. J., ... Stiefel, P. (2012). Olive oil polyphenols decrease blood pressure and improve endothelial function in young women with mild hypertension. American Journal of Hypertension, 25(12), 1299-1304. https://doi.org/10.1038/ajh.2012.128

Oboh, G., Bello, F. O., Ademosun, A. O., Akinyemi, A. J., \& Adewuni, T. M. (2015). Antioxidant, hypolipidemic, and anti-angiotensin-1-converting enzyme properties of lemon (Citrus limon) and lime (Citrus aurantifolia) juices. Comparative Clinical Pathology, 24(6), 1395-1406. https://doi.org/10.1007/s00580-015-2088-x

Violante, B., Gerbaudo, L., Borretta, G., \& Tassone, F. (2009). Effects of extra virgin olive oil supplementation at two different low doses on lipid profile in mild hypercholesterolemic subjects: A randomised clinical trial. Journal of Endocrinological Investigation, 32(10), 794796. https://doi.org/10.3275/6103

Wachidah Yuiwarti, E. Y., Saraswati, T. R., \& Kusdiyantini, E. (2018). Effect of VCO and olive oil on HDL, LDL, and cholesterol level of hyperglycemic Rattus Rattus Norvegicus. Journal of Physics: Conference Series, 1025(1). https://doi.org/10.1088/1742-6596/1025/1/012064

Yasmin, K., Khan, R., Syeda, A., \& Afshan, S. (2010). Evaluation of Hypolipidemic Effect of Citrus Lemon. Journal of Basic AND Applied Sciences Vol.6, No.1,. 6(January), 39-43. 